\title{
School performance at the end of elementary school: Contributions of intelligence, language, and executive functions
}

\author{
Desempenho escolar ao término do ensino fundamental \\ I: contribuições da inteligência, linguagem \\ e funções executivas
}

\author{
Natália Martins DIAS ${ }^{1}$ \\ Alessandra Gotuzo SEABRA²
}

\begin{abstract}
There are several variables that are associated with and that can influence school performance. The present study investigated the following: 1) the relationship between school performance and intelligence, language, and executive functions; 2) explanatory models for school performance. A total of 87 students in 5 th grade of elementary school, attending a public school in São Paulo State, Brazil (mean age $=9.72$, standard deviation $=0.58$ ), participated in this study. The participants were evaluated in terms of intelligence, language (phonological awareness and vocabulary), and executive functions (attention, cognitive flexibility, and working memory). Bimonthly grades were collected at the end of the school year. Results revealed significant correlations between school performance and all measures, except for attention. Students' performance on the cognitive tests explained up to $66 \%$ of their grades. Intelligence, language, and executive functions are associated with school performance, but language and executive functions, especially cognitive flexibility, can be considered as stronger predictors of performance in 5th grade. These findings can assist in the design and implementation of intervention programs to promote these skills.
\end{abstract}

Keywords: Cognition; Education; Evaluation; Learning.

\section{Resumo}

Diversas variáveis estão associadas e podem influenciar o desempenho escolar. Este estudo investigou: 1) a relação entre desempenho escolar e inteligência, linguagem e funções executivas; e 2) modelos explicativos do desempenho escolar. Participaram 87 estudantes do $5^{\circ}$ ano do ensino fundamental de uma escola pública do Estado de São Paulo (idade média =9,72; desvio-padrão =0,58), avaliadas em inteligência, linguagem (consciência fonológica e vocabulário) e funções executivas (atenção, flexibilidade, memória de trabalho). As notas bimestrais dos estudantes foram recolhidas

\footnotetext{
1 Centro Universitário Fundação Instituto de Ensino para Osasco, Programa de Pós-Graduação Stricto Sensu em Psicologia Educacional. Av. Franz Voegelli, 300, Bloco Prata, Continental, 06020-190, Osasco, SP, Brasil. Correspondência para/Correspondence to: N.M. DIAS. E-mail: <natalia.dias@unifieo.br>.

2 Universidade Presbiteriana Mackenzie, Programa de Pós-Graduação em Distúrbios do Desenvolvimento. São Paulo, SP, Brasil. Support: Fundação de Amparo à Pesquisa do Estado de São Paulo (Process n² 2012/50418-9) and Conselho Nacional de Desenvolvimento Científico e Tecnológico (Process nº 309625/2013-0).
} 
ao término do ano letivo. Resultados revelaram correlações significativas entre desempenho escolar e todas as medidas, exceto atenção. Os desempenhos nos testes cognitivos explicaram até $66 \%$ das notas escolares das crianças. Inteligência, linguagem e funções executivas relacionaram-se ao desempenho escolar, porém linguagem e funções executivas, especialmente a flexibilidade, podem ser considerados como preditores importantes na compreensão do desempenho de estudantes do $5^{\circ}$ ano. Implicações incluem a avaliação e delimitação de intervenções para promoção dessas habilidades.

Palavras-chave: Cognição; Educação; Avaliação; Aprendizagem.

School performance is a multidetermined variable influenced by biological, cognitive, emotional, educational, socio-cultural, and economic factors, among others (Siqueira \& GurgelGiannetti, 2011). The importance of investigating and understanding its determinants and associated variables arise from national and international evidence of poor performance of Brazilian students. For example, the Programme for International Student Assessment (PISA) between 2000-2012, carried out by the Organisation for Economic Cooperation and Development, have repeatedly highlighted the poor performance of Brazilian students, compared to students from other countries, not only in reading but also in science and mathematics (Organisation for Economic Co-operation and Development, 2013).

Intelligence has been one of the most widely studied cognitive constructs associated with academic achievement and consequently with school performance (Almeida, Guisande, Primi, \& Lemos, 2008; Dodonova \& Dodonov, 2012; Lemos, Almeida, Guisande, \& Primi, 2008; Oliveira \& Soares, 2011; Spinath, Freudenthaler, \& Neubauer, 2010). Despite the numerous theories of intelligence, including the general factor, $g$, proposed by Spearman and the hierarchical model of CattellHorn-Carroll, known as CHC (McGrew, 2009), the very definition of intelligence shows it is related to learning. For example, according to Sternberg (2008), intelligence is the ability to learn from experience. Corroborating this idea, in 1997, the journal Intelligence published an op-ed statement signed by leading researchers in the field defining intelligence as a general mental capability that involves the ability to reason, plan, solve problems, and think abstractly, and, once again, learn from
Evidence suggests that intelligence is a significant predictor of school performance in children and adolescents (Almeida et al., 2008; Dodonova \& Dodonov, 2012; Oliveira \& Soares, 2011). Although some specific components (e.g., verbal reasoning or numerical reasoning) have also been associated with performance of students, considerable importance can be attributed to the $g$ factor in explaining school performance (Almeida et al., 2008). There is also some evidence suggesting that programs aimed at improving intelligence can lead to the development of academic skills (Zampieri, Schelini, \& Crespo, 2012). On the other hand, although extremely important in the learning process, the relationship between intelligence and school performance seems to vary across grade levels, i.e., it tends to become less strong as the grade level increases, and it is likely that other abilities also play an important role throughout the school years (Lemos et al., 2008). Moreover, some studies have shown that other cognitive abilities are related to school performance. Among them is spoken language, and, more recently, executive functions.

The association between oral language and academic performance, more specifically reading performance, is already well established and widely explored in the literature (Cutting, Materek, Cole, Levine, \& Mahone, 2009; Monteiro \& Soares, 2014; Seabra \& Dias, 2012a; Skibbe et al., 2008). There is evidence of the particular contribution of specific oral language and reading skills, i.e., Phonological Awareness (PA, ability to identify and manipulate sound segments in words), to word recognition and contribution of vocabulary (a set of words which convey a meaning) to reading comprehension (Seabra \& Dias, 2012a). In addition, evidence suggests that these reading skills are also related to school performance (Dias, Seabra, \& Montiel, 2015). 
Based on this knowledge, the oral language skills selected to be used in the present study were PA and vocabulary. In addition to being important in the beginning of formal learning and to the fact that even at an early age these skills may predict later proficiency in reading (Torppa, Lyytien, Erskine, Eklund, \& Lyytinen, 2010), PA and vocabulary continue to develop throughout the school years and to influence student performance. For example, vocabulary is notably developed up to 12 years of age (Papalia, Olds, \& Feldman, 2009), and even in 5th grade (10 years old) students, along with syntactic knowledge, it is an important predictor of reading comprehension (Mokhtari \& Niederhauser, 2013). Similarly, evidence also suggests that the level of reading comprehension skills in the 4th grade contributes to the rate of vocabulary growth in later years (Duff, Tomblin, \& Catts, 2015). On the other hand, PA is a predictor of reading proficiency, even in adolescents with or without reading difficulties (Kairaluoma, Torppa, Westerholm, Ahonen, \& Aro, 2013). However, there is a reciprocal causality, in which lower levels of PA affect reading and writing acquisition and, in parallel, the progressive mastery of these skills can promote the development of more complex PA (Gombert, 2003). This is evident, for example, in the fact that in unschooled adults some aspects of PA are not fully developed (Mota, Vargas Romero, Kaminski, Vidor-Souza, \& Berticelli, 2012).

Strong evidence of the association between oral language and student performance can also be found in the literature. For example, Tenório and Ávila (2012) found significant correlations between the academic performance of students in the early years of elementary school in reading, writing, and arithmetic and their performance on a phonological processing test, especially when considering the measures of PA. In fact, oral language skills have been considered the main predictors of written language performance (Capovilla \& Dias, 2008; Dias \& Seabra, 2012; Scarborough, 2009; Skibbe et al., 2008; Torppa et al., 2010). There is also evidence of the causal relationship between these skills (Cuadro \& Trías, 2008; Seabra \& Capovilla, 2011).

More recently, some authors have highlighted the role of another set of skills, Executive Function
$(E F)$, in learning and school performance (Blair \& Diamond, 2008; Diamond, 2013; Seabra et al., 2014). EF is a set of processes that allow individuals to regulate their behavior, emotions and information processing (Lezak, Howieson, \& Loring, 2004). A current model considers three core EF: 1) inhibition, which enables the individual to inhibit inappropriate responses and distracting stimuli; it is related to the ability to control attention; 2) working memory, which allows for maintenance and manipulation of information; and 3) cognitive flexibility, the ability to change the focus of attention and consider different alternatives in the face of new and unexpected situations (Diamond, 2013).

There is evidence linking EF and school performance across a wide age range and in specific domains (see Seabra et al., 2014 for a complete review). For example, Best, Miller, and Naglieri (2011) evaluated children and adolescents (5-17 years) and found a relationship between executive function skills and academic performance in arithmetic and reading in all age groups. Moreover, among the executive function skills, some authors have highlighted the role of working memory in learning, suggesting that poor working memory skills constitute a risk factor for school failure. Those authors reiterate that working memory at the start of formal education is a more powerful predictor of subsequent academic success than Intelligence Quotient (T. Alloway \& Alloway, 2010).

Furthermore, experimental studies (reviewed by Diamond \& Lee, 2011) suggest that the relationship between EF and school performance is causal since intervention programs that promote EF development tend to transfer their effects to school performance. According to Meltzer (2010), this can be understood by the fact that children with EF difficulties often experience an overload of information, which can lead to disorganization and problems when beginning, resuming or completing tasks, affecting their performance in several areas. As a result, their grades would not reflect their actual intellectual ability (Meltzer \& Bagnato, 2010). Recently, a Brazilian study with children aged 2 to 5 years confirmed the relationship between EF and student performance in the three skills of writing, 
reading, and arithmetic, regarded as the fundamentals of education (Fonseca, Lima, Ims, Coelho, \& Ciasca, 2015).

According to the aforementioned discussion, it can be said that several studies have confirmed the relationship between school performance and intelligence, language, and EF. In fact, at the national level, research groups have devoted their attention to neuropsychological assessment of children and adolescents and to investigating the relationship between cognitive ability and school performance and learning (or learning difficulties). The importance of these studies has been highlighted since many cognitive components are involved in the learning process (Oliveira, Rodrigues, \& Fonseca, 2009). For example, it is known that in children in the early grades of elementary school, vocabulary and working memory are significant predictors of performance in word reading and reading comprehension tests (Piccolo \& Salles, 2013). Another study showed that working memory, EF, and the ability to write words and non-words are affected in 4th-6th grade students with reading comprehension difficulties (Corso, Sperb, \& Salles, 2013). On the other hand, there has been relatively less focus on mathematic skills in the scientific literature (Oliveira et al., 2009).

Accordingly, the present study addresses the abilities of three domains: intelligence, oral language, and EF. To measure school performance, an ecological measure was used, i.e., the students' bimonthly grades in all subjects throughout the school year. Therefore, the objectives of this study are: 1) investigate the relationship between school performance, specifically the bimonthly grades obtained during a school year, and intelligence $(g$ factor), oral language skills (PA and vocabulary), and EF (attention, working memory, and cognitive flexibility); 2) investigate explanatory models for school performance in order to determine whether oral language and EF can contribute to student performance even after controlling for intelligence and, if confirmed, to compare the relative contributions of each one of them. The sample studied comprised students in 5th grade, last year of elementary school (Ensino Fundamental-I, EF-I in
Brazil), an important period for the acquisition of basic skills. Thus, the present study will determine which skills are associated with and can contribute to school performance at the end of the first cycle of basic education. It is essential to understand the skills or abilities associated with school performance because they can help identify the causes for poor performance and the development of intervention strategies seeking improvement or problem solving.

\section{Method}

\section{Participants}

A total of 87 students in 5 th grade of a public elementary school (EF-l in Brazil) in the metropolitan region of Campinas, a city in the state of São Paulo $(111,620$ inhabitants, according to 2014 Instituto Brasileiro de Geografia e Estatísti-ca Census Brazilian Institute of Geography and Statistics) participated in this study. The participants were aged between 9 and 11 years $(M=9.72, S D=0.58)$, and $64.4 \%$ were girls. The exclusion criterion was the presence of intellectual disability (percentile $<5$ ), according to the Raven's Coloured Progressive Matrices (CPM) test, but this criterion was not met, and therefore no participants were excluded. In addition, according to school records, among the students in the sample, there was no child with uncorrected sensory impairment or known syndromes or psychiatric and neurological disorders. On the other hand, children with a history of grade retention were excluded from participation (total exclusions $=3$, including 2 children with one retention and 1 child with two retentions). The participating school was selected for convenience, and it was located in a neighborhood with mediumlow socioeconomic status and serves children from that neighborhood.

\section{Instruments}

Raven's Coloured Progressive Matrices Test - special scale (Angelini, Alves, Custódio, W.F. Duarte, \& Duarte, 1999): a non-verbal assessment 
of general intelligence, specifically Spearman's $g$ factor. The test items are presented in the form of visual patterns with a piece missing. The individuals have to choose the correct missing piece from a list of options. The special scale is intended to measure children from five to 11 years old. Administration time is estimated to take 30 minutes. The total score (number of correct answers) was converted into percentile according to the age of the participants.

Phonological Awareness Test by Oral Production (PCFO, Prova de Consciência Fonológica por Produção Oral) (Seabra \& Capovilla, 2012): assesses the ability to manipulate the sounds in spoken language. The test is composed of ten subtests including the assessment of supraphonemic and phonemic components: syllable synthesis and segmentation, phoneme synthesis and segmentation, rhymes and alliteration judgment, syllable and phoneme manipulation, and syllable and phoneme transposition. Each subtest is composed of two training items and four test items. See Seabra and Dias (2012b) for evidence of validity of this test.

Peabody Picture Vocabulary Test (PPVT) (L.M. Dunn \& Dunn, 1981): evaluates receptive vocabulary. The test items cover a broad range of semantic categories including people, actions, body parts, time, nature, places, objects, animals, mathematical terms, and tools. There are five training items and 125 test items. Each item consists of four pictures. The child is shown the pictures; the test administrator says a word, and the child must point to the picture that corresponds with the word. See Seabra and Capovilla (2009) for evidence of validity of this test.

Trail Making Test, Part B (TMTB) (Seabra \& Dias, 2012c): evaluates cognitive flexibility. It consists of the presentation of letters ( $A$ to $L$ ) and numbers (1 to 12 ) randomly arranged on a single sheet. The task is to connect the items following an alternating numeric and alphabetic sequence. There is a one-min limit for the administration of the test. The score is given per sequence, i.e., the number of items correctly connected in an unbroken sequence. See Dias, Menezes, and Seabra (2013) for evidence of validity of this test.
Cancellation Attention Test (TAC, Teste de Atenção por Cancelamento) (Seabra \& Dias, 2012c): evaluates aspects of selectivity and attention switching. It consists of three parts; each one contains a matrix with different stimuli (geometric shapes). The task is to identify all stimuli that are the same as the target stimulus. In the first part, the target stimulus is a single geometric figure; in the second part, the target stimulus is composed by two geometric figures. Both parts 1 and 2 assess selective attention. The third part evaluates selective and alternating attention as the target stimulus changes every line. The administration time is one minute for each part. The score used was the number of correct answers (number of target stimulus correctly canceled) in the entire test. See Dias et al. (2013) for evidence of validity of this test.

Auditory Working Memory Test (MTA, Teste de Memória de Trabalho Auditiva) (Primi, 2002): assesses auditory working memory. It is a computerized test, in which sequences of 2 to 10 items (words and numbers) are presented orally to the individual. The task is, firstly, to repeat the words in the same sequence they hear, and then to repeat the numbers in ascending order. The total score of correct sequences was used. Administration time is estimated to take 10 minutes. See Dias et al. (2013) for evidence of validity of this test.

Visual Working Memory Test (MTV, Teste de Memória de Trabalho Visual) (Primi, 2002): assesses visual working memory. It is a computerized test, in which one to four $3 \times 3$ matrices with a stimulus in each matrix are displayed on the screen. The individual then sees the spatial manipulations that are represented by arrows, indicating the stimulus' direction of motion. After executing the manipulations, the individual has to select with the mouse the final position of the stimulus. The total score of correct items was used. Administration time is estimated to take 20 minutes. See Dias et al. (2013) for evidence of validity of this test.

School grades were provided by the school board at the end of the school year. They were the participants' grades in the four quarters in Portuguese, Mathematics, Science, History, 
Geography, Arts, Physical Education, Computer Science, and English.

\section{Procedures}

The present study was approved by the Research Ethics Committee (Protocol n ${ }^{\circ} 137 / 04$ ) and was conducted after approval of the Municipal Secretary of Education. The participants included only the students who expressed interest and whose parents signed the written informed consent form. They were assured that all information collected would be kept strictly confidential, and the study was carried out in compliance with all ethical requirements. The assessments were carried out in the 2 nd semester of the school year. Initially, the TMTB and TAC instruments were collectively administered in a class session. The other instruments were then individually administered in five sessions in a separate room provided by the school during the regular school year. As previously mentioned, the bimonthly school grades were provided by the school board at the end of the year, and the average performance of the school year was determined.

The IBM-SPSS Statistics 20 (Statistical Package for Social Sciences, version 20.0) was used. A descriptive analysis of the cognitive test scores and school performance was carried out. Two school performance measures were considered: 1) the overall average performance in four academic quarters in all disciplines, namely Portuguese, Mathematics, Science, History, Geography, Arts, Physical Education, Computer Science, and English (Total School Performance); 2) the average performance in the four academic quarters in the five academic core subjects: Portuguese, Mathematics, Science, History, Geography (Core Discipline Performance). The Pearson correlation coefficient between the evaluated skills and school performance was calculated, and hierarchical regression analyses were carried out to identify different explanatory models for school performance. The variables added to the regression analysis were selected based on the correlation considered). The criterion variable was the Total School Performance, which showed stronger correlations with the other variables than that with the Core Discipline Performance. The explanatory variables used were the scores obtained in the Raven, PCFO, PPVT, TMTB-sequences, and MTA tests.

Two regression analyses were carried out. In the first one, intelligence was initially added as the explanatory variable (Step 1); next, the language variables (Step 2) were added, and finally the EF variables (Step 3) were added. In the second analysis, the entry order of the variables in the $2 \mathrm{nd}$ and $3 \mathrm{rd}$ steps was reversed. Thus, after controlling for intelligence (Step 1), the EF measures (Step 2) were added, and then the other measures were added (Step 3).

\section{Results}

Descriptive statistics for each cognitive and school performance measure are shown in Table 1. Significant correlations were observed between school performance and the cognitive measures, except for the TAC measures. High correlations were observed between school performance and language measures (PCFO and PPVT), moderate correlations between school performance and general intelligence (Raven), and moderate to low correlations between school performance and EF measures (moderate correlations with TMTB and MTA, and low with MTV). The coefficients are shown in Table 2.

The measures (variables) to be included in the regression analysis were selected based on the correlation analysis. The hierarchical model was chosen to test whether the language and EF measures could contribute to academic performance even after controlling for intelligence. The resulting explanatory models are presented in an integrated manner in Table 3 (all with satisfactory adjustment $(p<0.001)$.

In the first analysis, the test Raven, included as an explanatory variable in the first step (model 1), explained $34 \%$ of variance in student 
Table 1

Descriptive statistics for the cognitive and school performance measures

\begin{tabular}{|c|c|c|c|c|}
\hline Instrument/Measure & Mean & Standard Deviation & Minimum & Maximum \\
\hline Raven (percentil) & 59.34 & 23.99 & 10.0 & 99.0 \\
\hline PCFO & 30.26 & 5.69 & 15.0 & 40.0 \\
\hline PPVT & 85.46 & 9.42 & 62.0 & 105.0 \\
\hline TMTB - sequences & 8.70 & 5.87 & 0.0 & 21.0 \\
\hline TAC - correct answers & 71.70 & 21.26 & 0.0 & 98.0 \\
\hline MTA & 6.55 & 2.52 & 2.0 & 14.0 \\
\hline MTV & 3.19 & 2.50 & 0.0 & 12.0 \\
\hline Total School Performance & 6.80 & 1.40 & 3.7 & 9.7 \\
\hline Core Subject Performance & 6.40 & 1.80 & 2.0 & 10.0 \\
\hline
\end{tabular}

Note: PCFO: Phonological Awareness Test by Oral Production (Prova de Consciência Fonológica por Produção Oral); PPVT: Peabody Picture Vocabulary Test; TMTB: Trail Making Test, Part B; TAC: Cancellation Attention Test (Teste de Atenção por Cancelamento); MTA: Auditory Working Memory Test (Teste de Memória de Trabalho Auditiva); MTV: Visual Working Memory Test (Teste de Memória de Trabalho Visual).

Table 2

Correlation matrix between cognitive skills and school performance

\begin{tabular}{|c|c|c|c|}
\hline Instrument/Measure & & $\begin{array}{l}\text { Total school } \\
\text { performance }\end{array}$ & $\begin{array}{l}\text { Core subject } \\
\text { performance }\end{array}$ \\
\hline \multirow{2}{*}{ Raven } & $r$ & 0.58 & 0.55 \\
\hline & $p$ & 0.000 & 0.000 \\
\hline \multirow{2}{*}{ PCFO } & $r$ & 0.68 & 0.66 \\
\hline & $p$ & 0.000 & 0.000 \\
\hline \multirow{2}{*}{ PPVT } & $r$ & 0.65 & 0.64 \\
\hline & $p$ & 0.000 & 0.000 \\
\hline \multirow{2}{*}{ TMTB - sequences } & $r$ & 0.55 & 0.54 \\
\hline & $p$ & 0.000 & 0.000 \\
\hline \multirow{2}{*}{ TAC - correct answers } & $r$ & 0.19 & 0.18 \\
\hline & $p$ & 0.094 & 0.103 \\
\hline \multirow{2}{*}{ MTA } & $r$ & 0.40 & 0.40 \\
\hline & $p$ & 0.000 & 0.000 \\
\hline \multirow{2}{*}{ MTV } & $r$ & 0.37 & 0.34 \\
\hline & $p$ & 0.001 & 0.002 \\
\hline
\end{tabular}

Note: Significant findings are highlighted in bold.

PCFO: Phonological Awareness Test by Oral Production (Prova de Consciência Fonológica por Produção Oral); PPVT: Peabody Picture Vocabulary Test; TMTB: Trail Making Test, Part B; TAC: Cancellation Attention Test (Teste de Atenção por Cancelamento); MTA: Auditory Working Memory Test (Teste de Memória de Trabalho Auditiva); MTV: Visual Working Memory Test (Teste de Memória de Trabalho Visual).

performance. In the second step, the inclusion of the language variables increased the explanatory power of the model to 59\% (second model). Both language variables were important predictors of school performance, and with their inclusion, intelligence prediction was no longer significant. In the third step, the EF variables were added, generating a very consistent model (model 3), able to explain up to $66 \%$ of school performance. In this model, PA, vocabulary, cognitive flexibility, and (although marginally significant) auditory working memory have statistically significant regression coefficients; the intelligence measure still had no significant contribution.

In the second analysis, the first step was similar to that of the previous regression (model 1). However, in the second step, the EF skills were included generating a model (2b) able to explain up to $51 \%$ of the variance in school performance, with all variables included (Raven, TMTB-sequences, MTA) contributing with statistically significant regression coefficients. Finally, in the third step, the language variables were added, yielding similar results to those of the third step of the previous regression (model 3). It is worth mentioning that with the inclusion of the language measures, the performance of working memory was no longer a significant predictor of school performance (as it was in the second step), possibly due to the shared variance with the language measures.

\section{Discussion}

The results show that, according to the literature, school performance is related to different cognitive abilities, intelligence (Almeida et al., 2008; Dodonova \& Dodonov, 2012; Lemos et al., 2008; Oliveira \& Soares, 2011; Spinath et al., 2010), oral language (Capovilla \& Dias, 2008; Dias \& Seabra, 
Table 3

Explanatory models of school performance and regression coefficients of each skill included in the model

\begin{tabular}{|c|c|c|c|c|c|c|}
\hline & & $\beta$ & $t$ & $p$ & $R^{2}$ & Adjusted $R^{2}$ \\
\hline \multirow{2}{*}{1} & (Constant) & & 12.446 & 0.000 & \multirow{2}{*}{0.35} & \multirow{2}{*}{0.34} \\
\hline & Raven & 0.591 & 6.043 & 0.000 & & \\
\hline \multirow{4}{*}{$2 a$} & (Constant) & & -1.240 & 0.219 & \multirow{4}{*}{0.61} & \multirow{4}{*}{0.59} \\
\hline & Raven & 0.170 & 1.679 & 0.098 & & \\
\hline & PCFO & 0.388 & 3.771 & 0.000 & & \\
\hline & PPVT & 0.379 & 4.179 & 0.000 & & \\
\hline \multirow{4}{*}{$2 b$} & (Constant) & & 9.697 & 0.000 & \multirow{4}{*}{0.53} & \multirow{4}{*}{0.51} \\
\hline & Raven & 0.362 & 3.751 & 0.000 & & \\
\hline & TMTB-seq & 0.353 & 3.822 & 0.000 & & \\
\hline & MTA & 0.262 & 2.898 & 0.005 & & \\
\hline \multirow{6}{*}{3} & (Constant) & & -0.547 & 0.587 & \multirow{6}{*}{0.68} & \multirow{6}{*}{0.66} \\
\hline & Raven & 0.082 & 0.853 & 0.397 & & \\
\hline & PCFO & 0.362 & 3.833 & 0.000 & & \\
\hline & PPVT & 0.271 & 3.069 & 0.003 & & \\
\hline & TMTB-seq & 0.263 & 3.326 & 0.001 & & \\
\hline & MTA & 0.151 & 1.924 & 0.059 & & \\
\hline
\end{tabular}

Note: Significant findings are highlighted in bold.

Models: 1 - intelligence only; 2a - control for intelligence and inclusion of oral language; $2 \mathrm{~b}$ - control for intelligence and inclusion of executive functions; 3 - control for intelligence and inclusion of language and executive functions.

PCFO: Phonological Awareness Test by Oral Production (Prova de Consciência Fonológica por Produção Oral); PPVT: Peabody Picture Vocabulary Test; TMTB: Trail Making Test, Part B; TAC: Cancellation Attention Test (Teste de Atenção por Cancelamento); MTA: Auditory Working Memory Test (Teste de Memória de Trabalho Auditiva); MTV: Visual Working Memory Test (Teste de Memória de Trabalho Visual).

2012; Mokhtari \& Niederhauser, 2013; Piccolo \& Salles, 2013; Skibbe et al., 2008; Tenório \& Ávila, 2012), and EF (Blair \& Diamond, 2008; Diamond, 2013; Fonseca et al., 2015; Piccolo \& Salles, 2013; Seabra et al., 2014). Attention was the only one that did not correlate with children school performance. It is likely that in 5th grade, when there are more complex and challenging concepts, attention (a more basic skill), according to a cancellation assessment, is not sufficiently discriminative (or as discriminative as the other skills) among students with better or worse academic performance; it is important to highlight that a nonclinical sample of children was evaluated. Overall, the results show that children with higher level of general intelligence, larger vocabulary and better PA, greater cognitive flexibility, and strong working memory skills tend to have better grades.

Based on this initial finding, the subsequent regression analyses explored explanatory models of school performance based on the cognitive abilities investigated. The first model showed that general performance of children, which was expected, according to the review of previous studies in this area (Almeida et al., 2008; Lemos et al., 2008; Dodonova \& Dodonov, 2012; Oliveira \& Soares, 2011; Spinath et al., 2010; Zampieri et al., 2012). It is important to remember that the study sample did not include participants with intellectual disabilities; therefore, the analyses took into account the less extreme variations in this skill. Thus, general intelligence, when evaluated isolatedly, was a significant predictor of students' performance at the end of the 5 th grade.

After controlling the effect of intelligence, the inclusion of language skills and EF increased the explanatory power of the model, showing that both domains make unique contributions to school performance. It is worth highlighting, however, that with the inclusion of language variables (model 2a) the contribution of intelligence was no longer significant, i.e., PA and vocabulary, in that order, were better predictors of school performance than intelligence in the sample studied. This finding may be related to the age and educational level of the 
participants. In other words, oral language in general, and, specifically, PA and vocabulary are important predictors (regarded as precursors) of reading proficiency (Capovilla \& Dias, 2008; Cutting et al., 2009; Dias \& Seabra, 2012; Kairaluoma et al., 2013; Mokhtari \& Niederhauser, 2013; Scarborough, 2009; Seabra \& Dias, 2012a; Skibbe et al., 2008). Reading skills, in turn, are developed during the elementary years (EF-I in Brazil), and they are also related to school performance (Dias et al., 2015). Therefore, it is possible that the reading skills were not yet consolidated in this sample of 5 th graders and can be mediating this result. In older students, who already have good reading skills, this ability, and consequently oral language abilities, may exert a less significant effect on school performance.

Accordingly, although there is evidence that the PA is a predictor of reading proficiency, even in adolescents (Kairaluoma et al., 2013), its relationship with school performance found in the present study was stronger than expected. Thus, it is possible that reading proficiency (in terms of word recognition) was not yet fully developed in the sample studied, which would explain the still major role played by PA in the performance of those students. This fact may reflect a sampling bias or a problem in most Brazilian schools, where children reach the last grade of elementary school (EF-I in Brazil) without complete mastery of the written code. Another hypothesis is that the PA measure used has other requirements, which will be discussed further ahead.

Another noteworthy finding is related to the contribution of EF to the model. As expected, there was a unique contribution of EF to school performance, showing that these skills are indeed of great importance for the learning process (Blair \& Diamond, 2008; Diamond, 2013; Fonseca et al., 2015; Seabra et al., 2014). Cognitive flexibility, proved to be specially linked to school performance. This may suggest that the students which are more able to handle two or more sources of information simultaneously (such as paying attention to the teacher while taking notes) or those who are able to consider different approaches (e.g., trying different alternatives to solve a problem) are those who get better grades.
Comparing the contributions of oral language and $E F$, it was observed that the initial inclusion of language skills generated a model with higher explanatory power (model 2a) than that of the model with the initial inclusion of the EF skills (Model 2b). Moreover, in third step of the regressions, when all skills were included, working memory did not have a significant contribution to the final model, as it was expected (T. Alloway \& Alloway, 2010). One explanation for this finding is a possible overlap of the measures used, i.e., the PA tasks require, to some extent, processing or mental manipulation of information (for example, when blending the sounds $/ \mathrm{g} /, / \mathrm{a} /, / \mathrm{t} /, / \mathrm{O} /$, the child needs to hold all of these sounds in memory and blend them to form the word "gato", in Brazilian Portuguese. Similarly, in English it would be blending /c/, /a/, /t/ to form the word "cat"). Thus, it is likely that PA mediates part of the auditory working memory load related to school performance. This hypothesis is confirmed by analyzing model $2 \mathrm{~b}$, in which, before the inclusion of the language skills, auditory working memory contributed significantly to school performance prediction. Model 3, therefore, includes (possibly embedded in PA) the working memory load.

It is worth highlighting that although the final model is able to explain $66 \%$ of the variance in school performance, there is still some unexplained variance. In other words, approximately $44 \%$ of the variance in school performance could not be explained by intelligence, oral language, and EF. This result supports the conclusion reported by Oliveira et al. (2009) that there are many cognitive components involved in the learning process and thus in school performance. Future studies should explore other possible variables that can explain student performance.

Therefore, the present study provides evidence that although general intelligence is related to school performance, oral language and EF seem to have a greater contribution to the performance of students at the end of elementary school (EF-I in Brazil). At this school level, in which the basic academic skills are still being consolidated, children with better PA, vocabulary, and cognitive 
flexibility skills perform more competently at school and get higher grades. However, it should be pointed out that the present study had some limitations such as small number of participants, evaluation of only one school grade, and type of school. Thus, caution is required in generalizing the findings since aspects of the development and specific demands of the school grade investigated can influence these results. Therefore, future studies should extend this research to encompass different age groups and grade levels. Another limitation is related to the variables selected for this study, especially oral language, since PA and vocabulary may have greater effect during earlier grade levels. Accordingly, it is important that future studies extend these findings and investigate the role of other skills, such as syntactic and discourse skills, in school performance. Despite these limitations, the results found lead to the development of some hypotheses that can be tested in future research, such as that better oral language skills could lead to greater reading proficiency, and that greater cognitive flexibility will help students adequately cope with the demands of school work, resulting in higher grades.

Experimental studies should confirm this assumption; however these findings can assist in the design and implementation of intervention programs aimed at promoting cognitive development and impacting school performance. Thus, in addition to intelligence, these programs should include the promotion of language and executive skills. Similarly, the evaluation of these skills can be used to identify children that are at risk of school failure. These issues can be addressed and more extensively explored in future research.

\section{Final Considerations}

Given the evidence of poor performance of Brazilian students, the present study can provide a useful contribution to this area of research and to teachers and other professionals involved in education by identifying important skills related to school performance at the end of elementary school (EF-I in Brazil). This study showed that intelligence, oral language, and EF are associated with school performance. Moreover, it was also found that oral language, more specifically PA and vocabulary, and $E F$, especially cognitive flexibility, are stronger predictors of school performance of 5 th graders than intelligence. Thus, it can be said that these skills should be the target of intervention programs during the first years of formal schooling. This becomes even more interesting due to the availability of intervention programs to promote these skills, including in Brazil (Dias \& Mecca, 2015).

Accordingly, it is suggested that professionals devote closer attention to the stimulation and development of these skills. As for the researchers, new research questions are proposed for future studies: (e.g., Can other language skills, such as discursive skills, more complex ones, be more strongly associated to school performance? What skills are the most important and in which levels of education? Which are the long-term effects of stimulation of language and executive skills in childhood?). A more extensive body of evidence can, in the future, guide the development of public policies and practices to promote cognitive development and, consequently, impact student performance.

\section{Contributors}

N.M. Dias contributed to the conception and design of this study, development of the theoretical framework, data acquisition and analysis, and discussion and interpretation of the results. A.G. Seabra contributed to the definition of the objectives and to all stages of conception and design of this study.

\section{References}

Alloway, T., \& Alloway, R. G. (2010). Investigating the predictive roles of working memory and IQ in academic attainment. Journal of Experimental Child Psychology, 106(1), 20-29. https://doi.org/10.1016/j.jecp.2009. 11.003

Almeida, L., Guisande, M., Primi, R., \& Lemos, G. (2008). Contribuciones del factor general y de los factores específicos en la relación entre inteligencia y rendimiento escolar. European Journal of Education and Psychology, 1(3), 5-16. 
Angelini, A. L., Alves, I. C. B., Custódio, E. M., Duarte, W. F., \& Duarte, J. L. M. (1999). Manual - Matrizes Progressivas Coloridas de Raven, escala especial. São Paulo: Centro Editor de Testes e Pesquisas em Psicologia.

Best, J. R., Miller, P., \& Naglieri, J. (2011). Relations between executive function and academic achievement from ages 5 to 17 in a large, representative national sample. Learning and Individual Differences, 21(4), 327-336. https://doi.org/10.1016/j.lindif. 2011. 01.007

Blair, C., \& Diamond, A. (2008). Biological processes in prevention and intervention: The promotion of selfregulation as a means of preventing school failure. Development and Psychopathology, 20(3), 899-891. https://doi.org/10.1017/S0954579408000436

Capovilla, A. G. S., \& Dias, N. M. (2008). Habilidades de linguagem oral e sua contribuição para a posterior aquisição de leitura. PSIC, 9(2), 135-144.

Corso, H. V., Sperb, T. M., \& Salles, J. F. (2013). Comparação entre maus compreendedores e bons leitores em tarefas neuropsicológicas. Psicologia em Pesquisa, 7(1), 37-49. https://doi.org/10.5327/Z1982-1247 201300010005

Cuadro, A., \& Trías, D. (2008). Desarrollo de la conciencia fonémica: Evaluación de un programa de intervención. Revista Argentina de Neuropsicología, 11, 1-8.

Cutting, L. E., Materek, A., Cole, C. A. S., Levine, T. M., \& Mahone, E. M. (2009). Effects of fluency, oral language, and executive function on reading comprehension performance. Annals of Dyslexia, 59(1), 34-54. https://doi.org/10.1007/s11881-009-0 022-0

Diamond, A. (2013). Executive functions. Annual Review of Psychology, 64, 135-168. https://doi.org/10.11 46/ annurev-psych-113011-143750

Diamond, A., \& Lee, K. (2011). Interventions shown to aid executive function development in children 4 to 12 years old. Science, 333(6045), 959-964. https:// doi.org/10.1126/science. 1204529

Dias, N. M., \& Mecca, T. P. (2015). Contribuições da neuropsicologia e psicologia para intervenção no contexto educacional. São Paulo: Memnon.

Dias, N. M., Menezes, A., \& Seabra, A. G. (2013). Age differences in executive functions within a sample of Brazilian children and adolescents. The Spanish Journal of Psychology, 16, E9. https://doi.org/10.1017/sjp. 2013.12

Dias, N. M., \& Seabra, A. G. (2012). Relações entre linguagem oral e escrita na pré-escola e $1^{a}$ e $2^{a}$ série do ensino fundamental: estudo longitudinal das habilidades linguísticas preditoras do reconhecimento de palavras e da compreensão de leitura. In A. G. Seabra \& N. M. Dias (Orgs.), Avaliação neuropsicológica cognitiva: linguagem oral (pp.176-186). São Paulo: Memnon.
Dias, N. M., Seabra, A. G., \& Montiel, J. (2015). Development and interactions between academic performance, words recognition, listening, and reading comprehension. Psicologia: Reflexão e Crítica, 28(2), 404-415. https://doi.org/10.1590/1678-71 53.201528221

Dodonova, Y. A., \& Dodonov, Y. S. (2012). Processing speed and intelligence as predictors of school achievement: Mediation or unique contribution? Intelligence, 40(2), 163-171. https://doi.org/10.1016/ j.intell.2012.01.003

Duff, D., Tomblin, J. B., \& Catts, H. (2015). The influence of reading on vocabulary growth: A case for a Matthew effect. Journal of Speech, Language, and Hearing Research, 58(3), 853-864. https://doi.org/10.1044/ 2015_JSLHR-L-13-0310

Dunn, L. M., \& Dunn, L. M. (1981). Peabody picture vocabulary test-revised. Circle Pines: American Guidance Service.

Flores-Mendoza, C. E. (2010). Inteligência geral. In L. F. Malloy-Diniz, D. Fuentes, P. Mattos, \& N. Abreu (Orgs.), Avaliação neuropsicológica (pp.58-66). Porto Alegre: ArtMed.

Fonseca, G. U., Lima, R. F., Ims, R., Coelho, D. G., \& Ciasca, S. M. (2015). Evidências de validade para instrumentos de atenção e funções executivas e relação com desempenho escolar. Temas em Psicologia, 23(4), 843-858. https://doi.org/10.9788/TP2015.4-04

Gombert, J. E. (2003). Atividades metalinguísticas e aprendizagem da leitura. In M. R. Maluf (Org.), Metalinguagem e aquisição da escrita: contribuições da pesquisa para a prática da alfabetização (pp.19-64). São Paulo: Casa do Psicólogo.

Kairaluoma, L., Torppa, M., Westerholm, J., Ahonen, T., Aro, M. (2013). The nature of and factors related to reading difficulties among adolescents in a transparent orthography. Scientific Studies of Reading, 17(5), 315-332. https://doi.org/10.1080/10888438.2012. 701257

Lemos, G., Almeida, L., Guisande, M. D., \& Primi, R. (2008). Inteligência e rendimento escolar: Análise da sua associação ao longo da escolaridade. Revista Portuguesa de Educação, 21(1), 83-99.

Lezak, M. D., Howieson, D. B., \& Loring, D. W. (2004). Neuropsychological assessment (4th ed.). New York: Oxford University Press.

McGrew, K. S. (2009). CHC theory and the human cognitive abilities project: Standing on the shoulders of the giants of psychometric intelligence research. Intelligence, 37(1), 1-10. https://doi.org/10.1016/j. intell.2008.08.004

Meltzer, L. (2010). Promoting executive functions in the classroom. New York: The Guilford Press.

Meltzer, L., \& Bagnato, J. S. (2010). Shifting and flexible problem solving: The anchors for academic success. 
In L. Meltzer (Org.), Promoting executive functions in the classroom (pp.140-159). New York: The Guilford Press.

Mokhtari, K., \& Niederhauser, D. S. (2013). Vocabulary and syntactic knowledge factors in 5th grade students' reading comprehension. International Electronic Journal of Elementary Education, 5(2), 157-170.

Monteiro, S. M., \& Soares, M. (2014). Processos cognitivos na leitura inicial: relação entre estratégias de reconhecimento de palavras e alfabetização. Educação e Pesquisa, 40(2), 449-466.

Mota, H. B., Vargas Romero, M., Kaminski, T. I., VidorSouza, D., \& Berticelli, A. (2012). Desempenho de adultos não-letrados em avaliação das habilidades em consciência fonológica. Revista CEFAC, 14(2), 249-253. https://doi.org/10.1590/S1516-18462011005000 102

Organisation for Economic Co-operation and Development. (2013). PISA 2012 results: What students know and can do - student performance in mathematics, reading and science. Paris: OECD Publishing.

Oliveira, C. R., Rodrigues, J. C., \& Fonseca, R. P. (2009). $O$ uso de instrumentos neuropsicológicos na avaliação de dificuldades de aprendizagem. Revista Psicopedagogia, 26(79), 65-76.

Oliveira, M. B., \& Soares, A. B. (2011). Auto-eficácia, raciocínio verbal e desempenho escolar em estudantes. Psicologia: Teoria e Pesquisa, 27(1), 33-39. https://doi. org/10.1590/S0102-37722011000100005

Papalia, D. E., Olds, S. W., \& Feldman, R. D. (2009). Desenvolvimento humano. São Paulo: Artmed.

Piccolo, L. R., \& Salles, J. F. (2013). Vocabulário e memória de trabalho predizem desempenho em leitura de crianças. Psicologia: Teoria e Prática, 15(2), 180-191.

Primi, R. (2002). Bateria informatizada de capacidades cognitivas [Software]. Itatiba: Universidade São Francisco, 2002.

Scarborough, H. S. (2009). Connecting early language and literacy to later reading (dis)abilities: Evidence, theory and practice. In F. Fletcher-Campbell, J. Soler, \& G. Reid (Orgs.), Approaching difficulties in literacy development: Assessment, pedagogy and programmes (pp.23-38). London: The Open University.

Seabra, A. G., \& Capovilla, F. C. (2009). Teoria e pesquisa em avaliação neuropsicológica. São Paulo: Memnon.

Seabra, A. G., \& Capovilla, F. C. (2011). Problemas de leitura e escrita: como identificar, prevenir e remediar em uma abordagem fônica. São Paulo: Memnon.

Seabra, A. G., \& Capovilla, F. C. (2012). Prova de consciência fonológica por produção oral. In A. Seabra \& N. Dias (Orgs.), Avaliação neuropsicológica cognitiva:
Seabra, A. G., \& Dias, N. M. (2012a). Reconhecimento de palavras e compreensão de leitura: dissociação e habilidades linguístico-mnemônicas preditoras. Revista Neuropsicologia Latinoamericana, 4(1), 43-56.

Seabra, A. G., \& Dias, N. M. (2012b). Avaliação neuropsicológica cognitiva: linguagem oral. São Paulo: Memnon.

Seabra, A. G., \& Dias, N. M. (2012c). Avaliação neuropsicológica cognitiva: atenção e funções executivas. São Paulo: Memnon.

Seabra, A. G., Muniz, M., Reppold, C. T., Dias, N. M., Siquara, G., Tourinho, A. M. O., ... Teixeira, L. (2014). Funções executivas e desempenho escolar. In A. G. Seabra, J. A. Laros, E. C. Macedo, \& N. Abreu (Orgs.), Inteligência e funções executivas: avanços e desafios para a avaliação neuropsicológica (pp.211-225). São Paulo: Memnon.

Siqueira, C., \& Gurgel-Giannetti, J. (2011). Mau desempenho escolar: uma visão atual. Revista da Associação Médica Brasileira, 57(1), 78-87. https://doi.org/10.15 90/S0104-42302011000100021

Skibbe, L. E., Grimm K. J., Stanton-Chapman T. L., Justice L. M., Pence K. L., \& Bowles R. P. (2008). Reading trajectories of children with language difficulties from preschool through fifth grade. Language, Speech, and Hearing Services in Schools, 39(4), 475-486. https:// doi.org/10.1044/0161-146

Spinath, B., Freudenthaler, H. H., \& Neubauer, A. C. (2010). Domain-specific school achievement in boys and girls as predicted by intelligence, personality and motivation. Personality and Individual Differences, 48(4), 481-486. https://doi.org/10.1016/j.paid.2009. 11.028

Sternberg, R. J. (2008). Psicologia cognitiva. Porto Alegre: Artmed.

Tenório, S. M., \& Ávila, C. R. (2012). Processamento fonológico e desempenho escolar nas séries iniciais do ensino fundamental. CEFAC, 14(1), 30-38.

Torppa, M., Lyytinen, P., Erskine, J., Eklund, K., \& Lyytinen, H. (2010). Language development, literacy skills, and predictive connections to reading in Finnish children with and without familial risk for dyslexia. Journal of Learning Disabilities, 43(4), 308-321. https://doi.org/ $10.1177 / 0022219410369096$

Zampieri, M., Schelini, P., \& Crespo, C. (2012). Eficácia de um programa de estimulação de capacidades intelectuais. Estudos de Psicologia (Campinas), 29(3), 353-362. https://doi.org/10.1590/\$0103-166×20120 00300005

Received: February 4, 2015

Final version: January 21, 2016

Approved: May 10, 2016 